\title{
Peramalan Penjualan Sediaan Farmasi Menggunakan Long Short-term Memory: Studi Kasus pada Apotik Suganda
}

\author{
Maulana Ichwan Anshory ${ }^{* 1}$, Yusuf Priyandari ${ }^{2}$, dan Yuniaristanto ${ }^{3}$ \\ 1,2,3 Program Studi Teknik Industri, Fakultas Teknik, Universitas Sebelas Maret, \\ Jl. Ir. Sutami No.36 A, Surakarta, 57126, Indonesia \\ Email: maulanaia@outlook.com¹, priyandari@ft.uns.ac.id², yuniaristanto@staff.uns.ac.id ${ }^{3}$
}

DOI: 10.20961/performa.19.2.45962

\begin{abstract}
Abstrak
Peramalan data penjualan berperan penting dalam optimasi persediaan produk pada bisnis retail. Apotek adalah satu bentuk bisnis retail yang menjual sediaan farmasi (obat, bahan obat, obat tradisional dan kosmetik), alat kesehatan, dan bahan medis habis pakai. Apotek Suganda yang berlokasi di Kabupaten Sragen, melakukan penentuan rencana pengisian kembali (pembelian) sediaan farmasi dengan manual berbasis kebiasaan semata. Mekanisme tersebut terkadang menyebabkan terjadinya kekurangan persediaan obat. Oleh karena itu, untuk memperbaiki perencanaan pembelian, perlu dilakukan peramalan permintaan sediaan farmasi. Beberapa metode diujikan untuk melakukan peramalan permintaan, salah satunya menggunakan metode Long Short-term Memory (LSTM), yakni suatu metode berbasis machine learning. Bersama dengan metode-metode lainnya yakni Least Square, Single exponential Smoothing, Double exponential Smoothing, Triple Exponential Smoothing, Winter Exponential Smoothing, Weight Moving Average, dan ARIMA, peramalan penjualan sediaan farmasi dilakukan. Hasil pengujian menunjukkan bahwa peramalan penjualan sediaan farmasi secara mingguan yang menggunakan LSTM memiliki Mean Absolute Percentage Error (MAPE) yang paling rendah dibanding metode lainnya. Dengan demikian, implementasi peramalan penjualan berbasis machine learning perlu dimanfaatkan, salah satunya dengan membuat modul peramalan untuk diintegrasikan dengan aplikasi penjualan yang dimiliki oleh apotek tersebut.
\end{abstract}

Kata kunci: peramalan penjualan, sediaan farmasi, Long Short-term memory, machine learning

\begin{abstract}
Sales data forecasting plays an important role in optimization of retail business inventory. Pharmacy is a retail business that sells pharmaceutical products (medicines, medicinal ingredients, traditional medicines and cosmetics), medical devices, and consumable medical materials. Apotek Suganda, which is located in Sragen Regency, determines order quantity based on rule of thumb. This mechanism sometimes causes a shortage of drugs. Therefore, to improve purchasing planing, it is necessary to forecast the demand. Several methods have been tested to perform demand forecasting, one of it uses the Long Short-term Memory (LSTM) method, which is a machine learning-based method. Together with other methods, namely Least Square, Single exponential Smoothing, Double exponential Smoothing, Triple Exponential Smoothing, Winter Exponential Smoothing, Weight Moving Average, and ARIMA, sales forecasting were carried out. The test shows that the forecasting of weekly sales using LSTM has the lowest Mean Absolute Percentage Error (MAPE) compare to other methods. Thus, the implementation of sales forecasting based on machine learning needs to be utilized by creating a forecasting module which can be integrated in a sales application in the Apotek Suganda,
\end{abstract}

Keywords: Sales forecasting, pharmaceutical products, Long Short-term memory, machine learning

\section{Pendahuluan}

Peramalan merupakan metode untuk memprediksi kejadian di masa yang akan datang dengan menggunakan data masa lampau. Bagi perusahaan, peramalan adalah salah satu bentuk usaha untuk mendukung sebuah pengambilan keputusan (Kotler \& Keller, 2009). Peramalan penjualan atau permintaan produk merupakan aktivitas yang perlu dilakukan oleh perusahaan ritel, salah satu tujuannya untuk menghindari terjadi kekurangan persediaan (shortage). Apotek Suganda yang berlokasi di Kabupaten Sragen, selama ini melakukan perencanaan pembelian

\footnotetext{
* Corresponding author
} 
sediaan farmasi (obat, bahan obat, obat tradisional dan kosmetika) berdasarkan pengalaman praktis semata. Akibatnya, terkadang apotek kekurangan persediaan untuk memenuhi permintaan penjualan. Di sisi lain, penyediaan sediaan farmasi secara berlebihan tentunya menimbulkan biaya persediaan atau penimbunan modal. Oleh karena itu, Apotek Suganda perlu memprediksi permintaan penjualan menggunakan metode yang lebih baik.

Ada tiga klasifikasi metode peramalan secara umum yakni metode kualitatif, time series dan kausal (Render, Stair Jr, \& Hanna, 2012). Metode peramalan time series dibagi menjadi dua yaitu metode statistik dan machine learning (Makridakis, Spiliotis, \& Assimakopoulos, 2018). Metode statistik menggunakan pendekatan statistik, contohnya seperti regresi linier, dan exponential smoothing (Abraham \& Ledolter, 2009). Beberapa metode peramalan statistik yang telah digunakan untuk peramalan penjualan obat adalah Least Square (Kumalasari \& Rochmah, 2016; Rahmawati \& Wijanarko, 2019), Single Exponential Smoothing (Fachrurrazi, 2019), Triple Exponential Smoothing (Aprilianto \& Fauzi, 2016), Winter Exponential Smoothing (Affandi, Pradibta, \& Habibi, 2018), Weight Moving Average (Hendriani, Yamin, \& Dewi, 2016) dan AutoRegressive Integrated Moving Average (ARIMA) (Zahra, 2019).

Metode machine learning adalah algoritma yang memungkinkan pengguna untuk menemukan dan menggambarkan pola struktur dalam data, sehingga dengan menggunakan pola struktur dalam data tersebut, machine learning melakukan peramalan data masa yang akan datang (Witten \& Frank, 2002). Dibandingkan dengan metode statistik tradisional, metode machine learning melakukan peramalan lebih baik karena dapat mengakomodasi hubungan non-linier dan kompleks antara input dan output (Friedman, Hastie, \& Tibshirani, 2001). Deep learning adalah salah satu bagian dari machine learning (Guo et al., 2016). Kemudian salah satu metode peramalan time series dari kelompok deep learning adalah Long Short-Term Memory (LSTM) yang berbasis Recurrent Neural Network (RNN) dengan akurasi yang baik. Beberapa penelitian telah menggunakan metode LSTM sebagai metode peramalan time series, sebagai contoh untuk peramalan kunjungan wisata (Sugiartawan, Permana, \& Prakoso, 2018), harga saham (Arfan, 2019) dan nilai tukar mata uang (Hastomo \& Satyo, 2019).

Pada studi kasus peramalan permintaan sediaan farmasi di Apotek Suganda, diujikan metode-metode tersebut. Metode yang memberikan akurasi yang baik, nantinya dipertimbangkan untuk digunakan sebagai komponen di dalam modul peramalan pada aplikasi penjualan di apotek tersebut.

\section{Metodologi Penelitian}

Tahapan penelitian menggunakan prinsip pengolahan data pada metodologi data analytic (Erl, Khattak, \& Buhler, 2016). Tahapan tersebut yakni analisis proses bisnis, identifikasi data, pengumpulan dan penyaringan data, validasi dan pembersihan data dan analisis data. Prosesproses pengolahan data menggunakan bahasa pemrograman Python dengan aplikasi Jupyter Notebook sebagai antarmukanya dan menggunakan library pendukung seperti pandas, numpy, keras, statsmodel, scipy, mysql dan math.

Pada tahapan analisis proses bisnis, dilakukan observasi mengenai bagaimana pihak apotek melakukan proses peramalan permintaan produk yang dijadikan landasan untuk pemesanan kepada pemasok. Tahapan selanjutnya, yakni identifikasi data, dilakukan identifikasi data dan sumber data untuk peramalan permintaan. Setelah itu, dilakukan tahapan akuisisi data, yang dilanjutkan dengan tahapan validasi data dan pembersihan data. Validasi dan pembersihan data digunakan untuk mengidentifikasi kemungkinan data yang tidak relevan atau bahkan data hilang pada proses akuisisi. Teknik visualisasi data juga dilakukan pada tahapan tersebut untuk membantu menganalisis kondisi data yang tersedia. Proses interpolasi data dipertimbangkkan untuk digunakan jika ada data hilang, atau akan digunakan teknik-teknik lain sesuai kondisi data yang diperoleh. 
Tahapan terakhir adalah analisis data. Pada tahapan ini diujikan beberapa metode peramalan yakni Least Square, Single Exponential Smoothing, Double Exponential Smoothing, Triple Exponential Smoothing, Winter Exponential Smoothing, Weight Moving Average, ARIMA, dan terakhir LSTM. Oleh karena pengolahan menggunakan library yang telah tersedia pada Python, deskripsi rumusan pada setiap metode tidak dijelaskan detail pada artikel ini, tetapi dapat merujuk pada referensi-referensi utama yang berkaitan dengan metode-metode tersebut. Artikel ini mengfokuskan pada penyajian hasil pengolahan peramalan yang diperoleh pada antarmuka aplikasi Jupyter Notebook. Tidak semua data dianalisis, tetapi dipilih secara acak salah satu produk sediaan farmasi. Diasumsikan bahwa setiap jenis produk memiliki pola permintaan yang tidak berbeda. Parameter-parameter yang digunakan pada masing-masing metode peramalan adalah parameter yang menghasilkan Mean Absolute Percentage Error (MAPE) terkecil.

Validasi hasil peramalan dilakukan menggunakan metode one-step-ahead forecasting atau peramalan satu langkah ke depan. Secara umum, one-step ahead forecasting dilakukan dengan memanfaatkan nilai saat ini dan nilai yang diamati dari variabel tertentu untuk memperkirakan nilai yang diharapkan untuk langkah waktu berikutnya. Memprediksi dua atau lebih langkah ke depan dianggap sebagai masalah multi-step ahead forecasting, yang sering dilambangkan dengan prediksi $h$-langkah di depan, di mana $h$ sesuai dengan horizon prediksi (ElMoaqet, Tilbury, \& Ramachandran, 2016).

\section{Hasil dan Pembahasan}

Berikut ini disajikan hasil-hasil analitika data penjualan sediaan farmasi pada studi kasus di Apotek Suganda.

\subsection{Analisis proses bisnis}

Pihak Apotek Suganda tidak secara khusus melakukan prediksi penjualan. Kuantitas pesan yang dilakukan kepada pemasok didasarkan pada kebiasaan pembelian sebelumnya, atau berdasarkan pertimbangan tertentu yang menjadi wewenang pemilik apotek. Saat observasi dilakukan, juga sedang berlangsung proses implementasi aplikasi penjualan secara terkomputerisasi. Aplikasi penjualan yang digunakan belum memiliki modul untuk peramalan permintaan produk.

Berdasarkan diskusi dengan pegawai apotek, diketahui bahwa ternyata ada kalanya persediaan obat habis. Potensi kehilangan penjualan tersebut tidak selalu diatasi dengan penambahan kuantitas pemesanan pada periode berikutnya karena pemilik apotek juga mempertimbangkan jumlah sediaan yang tidak terlalu banyak. Persediaan yang banyak berarti melakukan penimbunan modal usaha dan menimbulkan kemungkinan adanya sediaan kadaluarsa. Proses pemesanan kepada pemasok biasanya dilakukan setiap ada pegawai dari pedagang besar obat yang datang ke apotek. Waktunya beragam dan tidak tentu, bisa seminggu sekali hingga sebulan sekali. Masing-masing pedagang besar obat, biasanya memasok jenis sediaan farmasi tertentu (spesifik), atau ada juga jenis sediaan yang bisa dipasok dari beberapa pemasok. Kondisi ini menjadikan mekanisme peramalan permintaan yang lebih baik perlu digunakan untuk memprediksi kuantitas pesan yang lebih optimal.

\subsection{Identifikasi data dan sumber data}

Data yang bisa diberikan oleh pihak apotek untuk penelitian adalah data lama, yakni data tahun 2019. Diperoleh data penjualan dan pembelian antara tanggal 1 Juni 2019 hingga 30 September 2019. Data tersebut pada awalnya masih berbentuk catatan penjualan dan pembelian obat yang terekam dalam buku. Data tersebut kemudian dimasukkan ke dalam aplikasi penjualan atau point of sales $(\mathrm{PoS})$ dan kemudian dipindahkan ke dalam spreadsheet. 


\subsection{Akuisisi data, validasi dan pembersihan}

Dilakukan penarikan data (retrieve) berupa data sediaan farmasi atau selanjutnya disebut data produk, data pemasok (biasanya berupa pedagang besar obat atau produsen obat), data transaksi pemesanan (order), data penerimaan (receiving) dan detail kuantitas penerimaan produk, data transaksi penjualan (sales) dan detail kuantitas penjualan produk. Program python dan GUI Jupyter Notebook digunakan untuk menarik data. Selanjutnya data disimpan dalam file berekstensi *.csv untuk kemudahan pengolahan data lanjutan. Gambar 1 menampilkan tabel data produk di Apotek Suganda, kemudian gambar 2 data pemasok.

\begin{tabular}{|c|c|c|c|c|c|c|}
\hline \multicolumn{7}{|c|}{ size cost_price } \\
\hline & 0 & 1 & Abate & sachet & 2200.0 & 2500.0 \\
\hline & 1 & 2 & Acifar 400 & strip & 10798.0 & 12000.0 \\
\hline & 2 & 3 & Acifar Cream 5gr & tube & 4900.0 & 5500.0 \\
\hline & 3 & 4 & Acitral Syrup 60ml & Botol & 32000.0 & 35500.0 \\
\hline & 4 & 5 & Acitral Tab $10 \mathrm{~s}$ & Strip & 10750.0 & 12000.0 \\
\hline & $\cdots$ & $\cdots$ & $\cdots$ & $\cdots$ & & $\cdots$ \\
\hline & 1224 & 1258 & Zoloral $2 \%$ Cream 10gr & tube & 20000.0 & 22500.0 \\
\hline & 1225 & 1259 & Zoralin 200mg & strip & 24600.0 & 27500.0 \\
\hline & 1226 & 1260 & Zoralin Cream 10gr Medikon & tube & 18900.0 & 21000.0 \\
\hline & 1227 & 1261 & Zoralin Cream 2\% & tube & 11100.0 & 12500.0 \\
\hline & 1228 & 1262 & Zyloric Tablet $100 \mathrm{mg} 60 \mathrm{~s}$ & tablet & 2211.0 & 2500.0 \\
\hline
\end{tabular}

Gambar 1. Data sediaan farmasi (produk)

\begin{tabular}{|crrr|}
\hline Out [33]: & & person_id & company_name \\
\cline { 2 - 3 } & 0 & 2 & Apotek Suganda \\
1 & 3 & SMF \\
2 & 4 & IGM \\
3 & 5 & DPS \\
4 & 6 & SYM \\
5 & 7 & BMJ \\
6 & 8 & ASAM \\
7 & 9 & SPS \\
8 & 10 & PRTS \\
9 & 11 & PIM \\
10 & 12 & SBS \\
11 & 13 & BMS \\
12 & 14 & PM \\
13 & 15 & SYM \\
14 & 16 & APL \\
15 & 17 & AMS \\
16 & 18 & ASA \\
17 & 19 & BKM \\
\hline
\end{tabular}

Gambar 2. Data pemasok 
Gambar 3 (a) menampilkan data transaksi pemesanan produk kepada pemasok dan gambar 3 (b) data transaksi penerimaan produk. Kedua data tersebut menginformasikan bahwa pada tanggal 26 Mei 2019 dilakukan transaksi pemesanan, yang kemudian terjadi penerimaan pada 1 Juni 2019 atau ada lead time dari saat pemesanan sampai terjadi penerimaan produk. Adapun detail kuantitas produk yang diterima, terdapat dalam tabel lain yang tidak disajikan di sini.

\begin{tabular}{|c|c|c|c|c|c|}
\hline \\
\hline & \multicolumn{5}{|c|}{ ordering_id supplier_id receiving_id } \\
\hline & 1 & 2 & 14 & 2 & 2019-05-26 \\
\hline & 2 & 3 & 8 & 3 & $2019-05-28$ \\
\hline & 3 & 4 & 4 & 4 & 2019-06-01 \\
\hline & 4 & 5 & 5 & 5 & $2019-05-28$ \\
\hline & $\ldots$ & $\ldots$ & & & \\
\hline & 117 & 118 & 6 & 118 & 2019-09-18 \\
\hline & 118 & 119 & 17 & 119 & 2019-09-22 \\
\hline & 119 & 120 & 17 & 120 & 2019-09-21 \\
\hline & 120 & 121 & 16 & 121 & 2019-09-25 \\
\hline & 121 & 122 & 10 & 122 & 2019-09-26 \\
\hline
\end{tabular}

(a)

\begin{tabular}{|crrrr|}
\hline Out [63]: & & receiving_time & supplier_id & receiving_id \\
\cline { 2 - 5 } & 0 & $2019-06-01$ & 4 & 1 \\
1 & $2019-06-02$ & 14 & 2 \\
2 & $2019-06-03$ & 8 & 3 \\
3 & $2019-06-04$ & 4 & 4 \\
4 & $2019-06-05$ & 5 & 5 \\
$\ldots$ & & $\ldots$ & $\ldots$ \\
117 & $2019-09-26$ & 6 & 118 \\
118 & $2019-09-27$ & 17 & 119 \\
119 & $2019-09-28$ & 17 & 120 \\
120 & $2019-09-29$ & 16 & 121 \\
121 & $2019-09-30$ & 10 & 122 \\
122 rows $\times 3$ columns & & \\
\hline
\end{tabular}

(b)

Gambar 3. Data transaksi ( a) pemesanan produk, dan (b) penerimaan produk dari pemasok

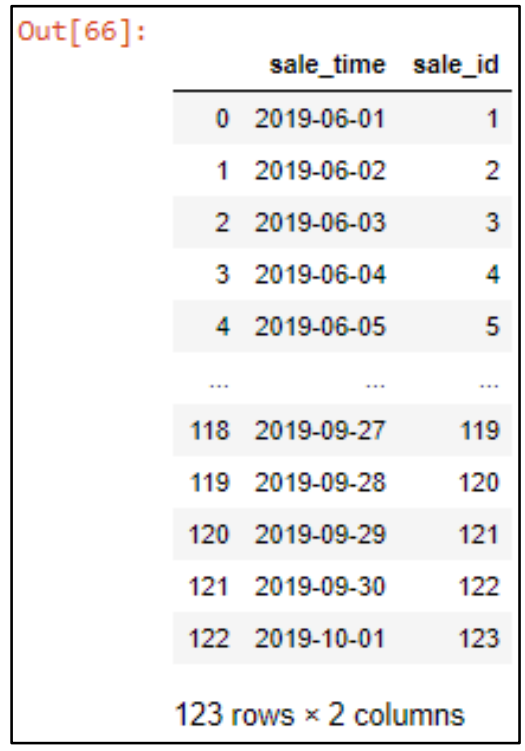

(a)

\begin{tabular}{|c|c|c|c|c|}
\hline \multicolumn{5}{|l|}{ Out [67]: } \\
\hline & 0 & 1 & 1 & 3.0 \\
\hline & 1 & 1 & 14 & 2.0 \\
\hline & 2 & 1 & 15 & 3.0 \\
\hline & 3 & 1 & 16 & 1.0 \\
\hline & 4 & 1 & 19 & 1.0 \\
\hline & $\ldots$ & $\ldots$ & $\ldots$ & $\ldots$ \\
\hline & 56888 & 123 & 1250 & 3.0 \\
\hline & 56889 & 123 & 1252 & 1.0 \\
\hline & 56890 & 123 & 1259 & 2.0 \\
\hline & 56891 & 123 & 1261 & 3.0 \\
\hline & 56892 & 123 & 1262 & 1.0 \\
\hline \multicolumn{5}{|c|}{56893 rows $\times 3$ columns } \\
\hline
\end{tabular}

(b)

Gambar 4. Data (a) transaksi penjualan; (b) detail kuantitas penjualan produk

Gambar 4 (a) menyajikan data transaksi penjualan dan (b) detail kuantitas penjualan. Sebagai contoh, pada tanggal 1 Juni 2019 terdapat transaksi penjualan dengan produk-produk terjual yakni produk 1 sebanyak 3 satuan, produk 14 sebanyak 2 satuan, produk 15 sebanyak 3 satuan, dan seterusnya. Relasi kedua tabel tersebut menghasilkan data time series penjualan produk.

Tahap validasi dan pembersihan data merupakan proses yang panjang dan dilakukan secara bertahap. Validasi menurut (Essnet Validat Foundation, 2016) ada beberapa level, pada tahapan ini hanya dilakukan pengecekan level 0 yakni memastikan data yang dipanggil (query) menghasilkan data set yang sesuai. Pembersihan data lanjutan tidak menemukan data duplikasi pada item sediaan farmasi. Beberapa kesalahan pengetikan pada nama produk dan satuan 
ditemukan dan dilakukan perbaikan. Meskipun demikian, diasumsikan bahwa hal tersebut tidak berpengaruh terhadap proses peramalan pemintaan sediaan farmasi.

Selanjutnya dilakukan beberapa visualisasi data. Pertama visualisasi distribusi penjualan seperti gambar 5. Diperoleh informasi bahwa 59\% kuantitas penjualan antara 1 sampai 3 unit, kemudian 21\% kuantitas penjualan antara 3 sampai 6 unit. Dengan kata lain, bahwa 80\% penjualan antara 1 sampai 6 unit selama horizon data penjualan yang diolah.

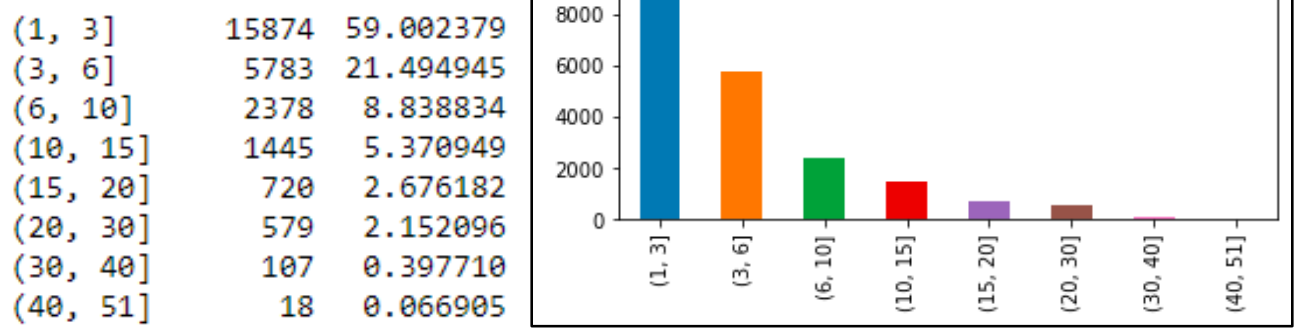

Gambar 5. Distribusi penjualan per item produk

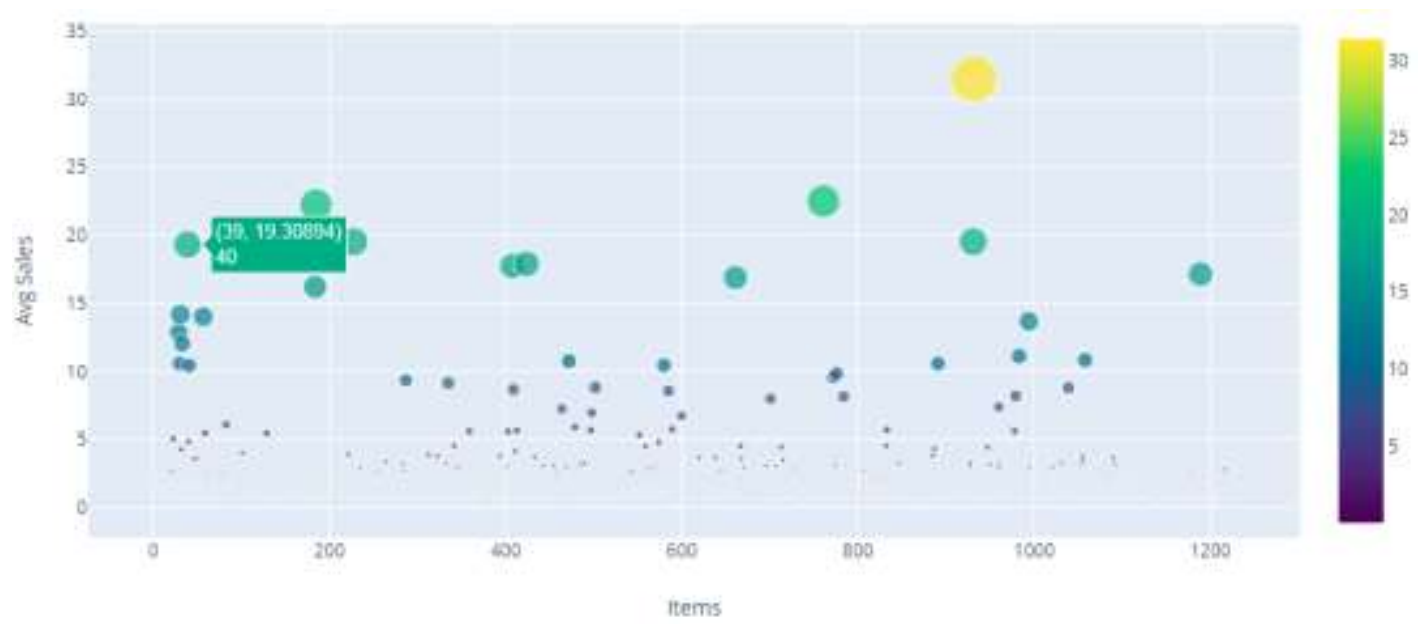

Gambar 6. Visualisasi rata-rata penjualan per- produk

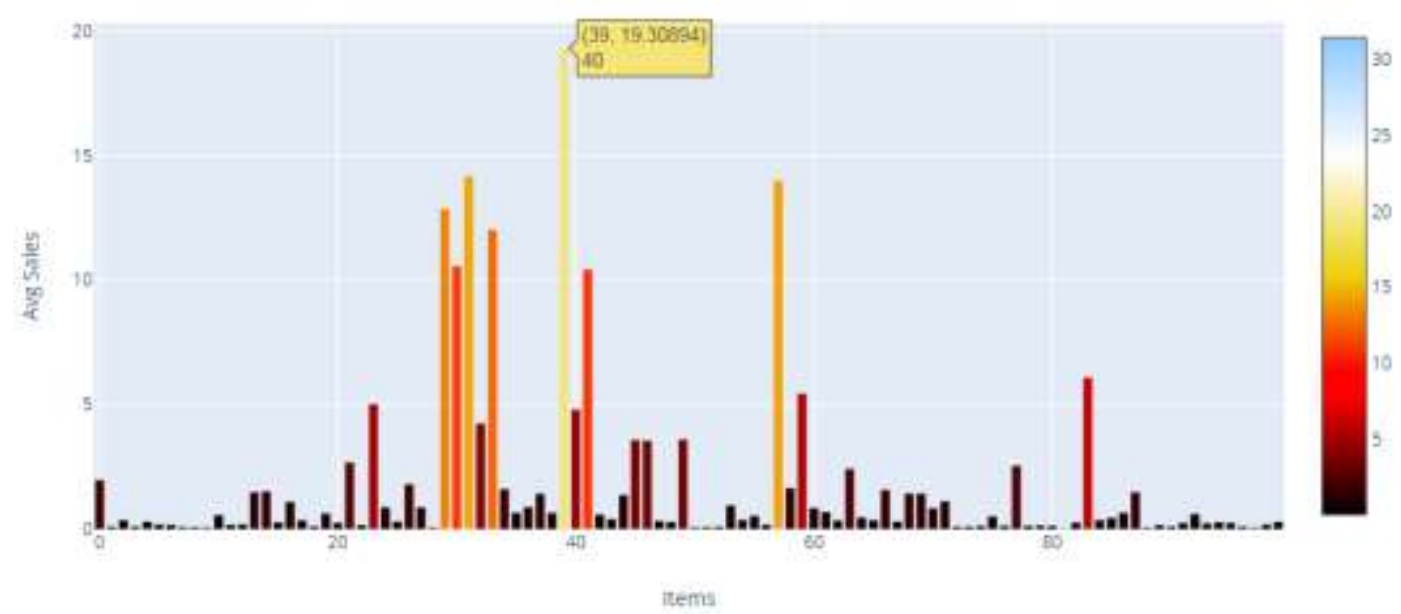

Gambar 7. Visualisasi rata-rata penjualan untuk 100 produk pertama 
Gambar 6 memberikan visualisasi rata-rata kuantitas penjualan untuk seluruh produk, yakni sebanyak 1229 item produk. Adapun gambar 7 menunjukkan grafik batang rata-rata penjualan untuk 100 item produk pertama (berdasarkan kode atau item_id produk). Sebagai contoh, produk dengan nomor (item_id) 40 memiliki rata-rata penjualan sebesar 19,3 unit.

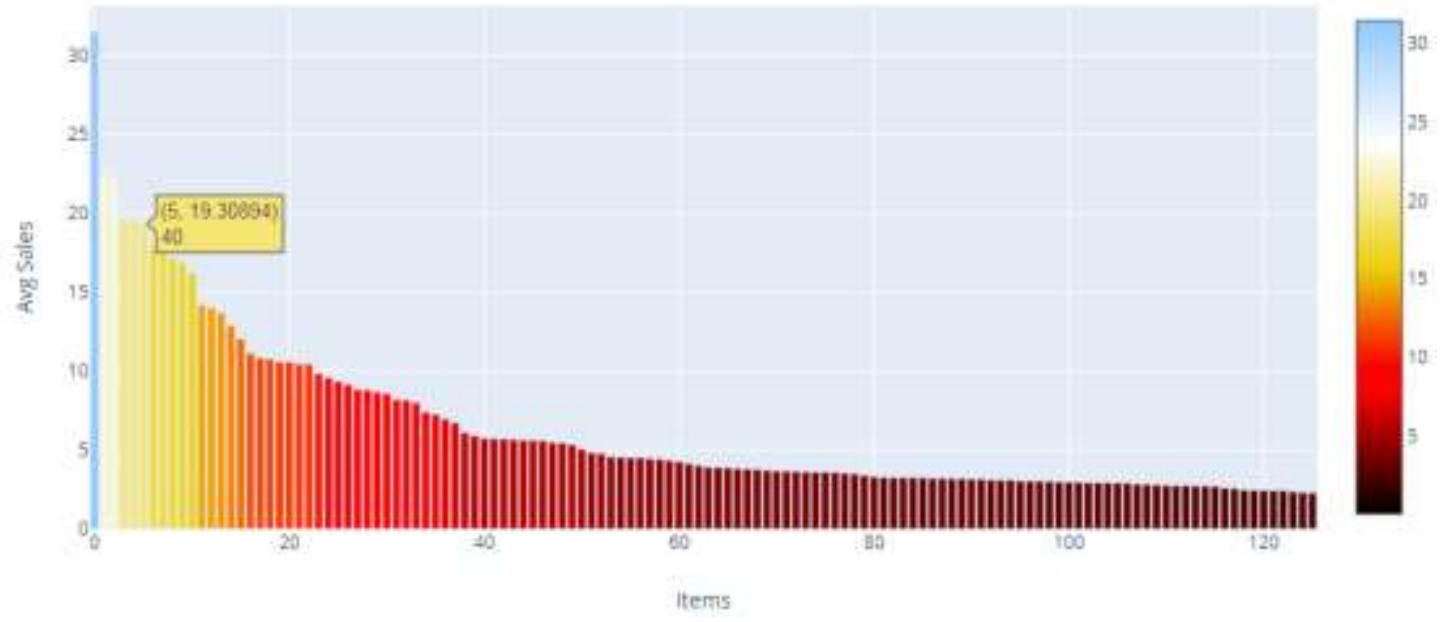

Gambar 8. Visualisasi 10\% produk dengan rata-rata kuantitas penjualan yang besar

Visualisasi pada gambar 8 menampilkan informasi sepuluh persen produk atau sebanyak 125 item produk dengan rata-rata kuantitas penjualan tinggi. Visualisasi-visualisasi tersebut menunjukkan bahwa pada produk nomor 40, memiliki rata-rata penjualan 19,3 unit satuan. Hasil verifikasi terhadap item produk nomor 40 seperti disajikan pada gambar 9. Jika dirata-rata pada atribut clean_sale, kuantitas penjualan sebesar 19,3 unit satuan.

\begin{tabular}{|c|c|c|c|c|c|c|c|}
\hline time & item_id & clean_sale & nama_obat & kategori & satuan & harga_jual & produsen \\
\hline 2019-10-01 & 40 & 14 & Ambroxol Tablet $30 \mathrm{mg} 100 \mathrm{~s}$ & GK & tablet & 3500 & INDOFARMA \\
\hline 2019-06-03 & 40 & 25 & Ambroxol Tablet $30 \mathrm{mg} 100 \mathrm{~s}$ & GK & tablet & 3500 & INDOFARMA \\
\hline 2019-08-05 & 40 & 26 & Ambroxol Tablet $30 \mathrm{mg} 100 \mathrm{~s}$ & GK & tablet & 3500 & INDOFARMA \\
\hline 2019-08-15 & 40 & 19 & Ambroxol Tablet $30 \mathrm{mg} 100 \mathrm{~s}$ & GK & tablet & 3500 & INDOFARMA \\
\hline $2019-07-03$ & 40 & 21 & Ambroxol Tablet $30 \mathrm{mg} 100 \mathrm{~s}$ & GK & tablet & 3500 & INDOFARMA \\
\hline 2019-08-06 & 40 & 17 & Ambroxol Tablet $30 \mathrm{mg} 100 \mathrm{~s}$ & GK & tablet & 3500 & INDOFARMA \\
\hline $2019-07-20$ & 40 & 20 & Ambroxol Tablet $30 \mathrm{mg} 100 \mathrm{~s}$ & GK & tablet & 3500 & INDOFARMA \\
\hline
\end{tabular}

Gambar 9. Verifikasi sample data penjualan produk dengan nomor item_id 40

Tentunya, tidak setiap hari terjadi transaksi penjualan obat, sehingga apabila menggunakan data mentah dari basis data, kuantitas penjualan produk bernilai Null. Hal tersebut menyebabkan data time series seolah-olah terputus. Pembersihan data dilakukan dengan mengubah nilai Null menjadi angka 0 atau melakukan interpolasi data untuk memberikan nilai tertentu. Grafik time series penjualan produk nomor 40 pada gambar 10, dan beberapa item produk pada gambar 11 .

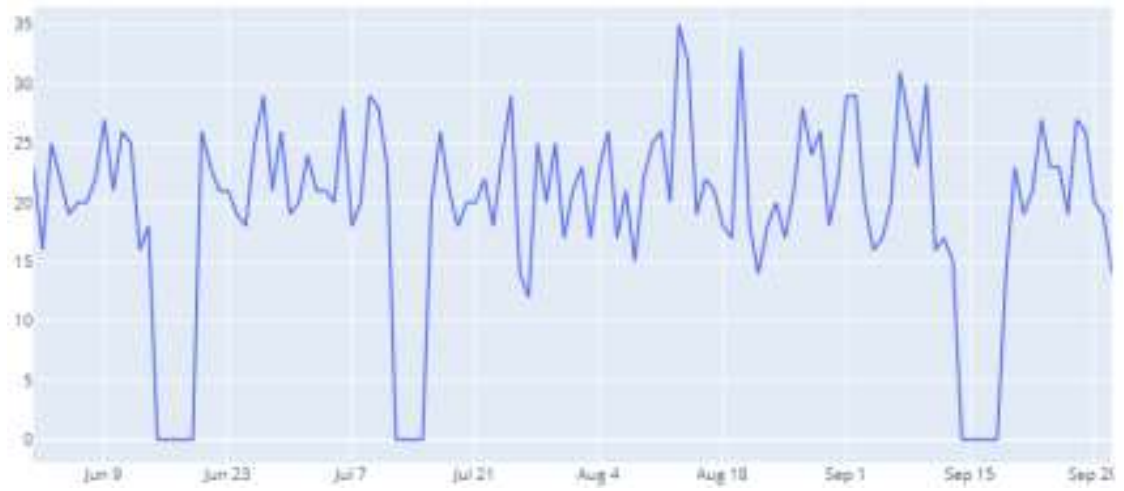

Gambar 10. Time series penjualan produk, nomor item_id 40 


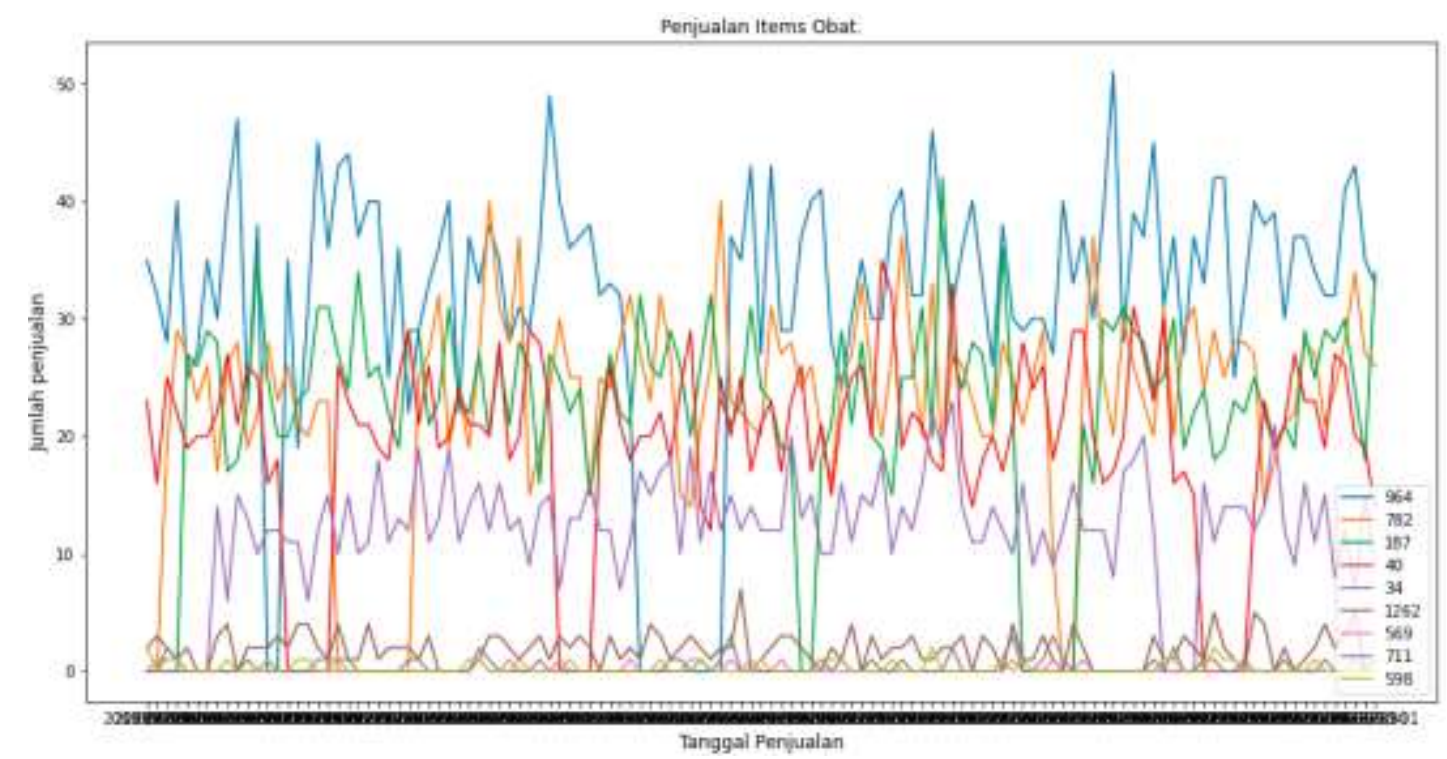

Gambar 11. Time series penjualan beberapa item produk

\subsection{Analisis data}

Oleh karena banyaknya produk sediaan farmasi pada apotek, di dalam artikel ini disajikan satu contoh hasil pengolahan data peramalan menggunakan metode-metode yang diujikan. Proses peramalan menggunakan program Python dan library yang diperlukan. Setiap metode dilihat nilai Mean Absolute Percentage Error (MAPE). Berikut ini pada tabel 1, disajikan hasil pengolahan peramalan permintaan harian pada untuk bulan September 2019 menggunakan Least Square.

Tabel 1. Peramalan Piroxicam KF 20mg menggunakan Metode Least Square.

\begin{tabular}{clll}
\hline Tanggal & Penjualan & Peramalan & APE $(\%)$ \\
\hline $08-06-2019$ & 30 & 29,8571 & 0,4762 \\
$09-06-2019$ & 40 & 29,1667 & 27,0833 \\
$10-06-2019$ & 47 & 33,6944 & 28,3097 \\
$\ldots$ & $\ldots$ & $\ldots$ & $\ldots$ \\
$29-09-2019$ & 43 & 35,1020 & 18,3674 \\
$30-09-2019$ & 35 & 35,3781 & 1,0803 \\
& & & \\
\hline
\end{tabular}

Tabel 2. Peramalan Piroxicam KF 20mg menggunakan Single Exponential Smoothing

\begin{tabular}{clll}
\hline Tanggal & Penjualan & Peramalan & APE $(\%)$ \\
\hline $07-06-2019$ & 35 & - & - \\
$08-06-2019$ & 30 & 35,0000 & 16,6667 \\
$09-06-2019$ & 40 & 34,5000 & 13,7500 \\
$\ldots$ & $\ldots$ & $\ldots$ & $\ldots$ \\
$28-09-2019$ & 41 & 34,8467 & 15,0081 \\
$29-09-2019$ & 43 & 35,4620 & 17,5302 \\
$30-09-2019$ & 35 & 36,2158 & 3,4737 \\
& & & \\
\hline
\end{tabular}

Tabel 3. Peramalan Piroxicam KF 20mg menggunakan Metode Double Exponential Smoothing

\begin{tabular}{clllllll}
\hline Tanggal & Penjualan & $\begin{array}{c}\text { Single } \\
\text { Exponential }\end{array}$ & $\begin{array}{c}\text { Double } \\
\text { Exponential }\end{array}$ & a & b & Peramalan & $\begin{array}{c}\text { APE } \\
(\%)\end{array}$ \\
\hline $06-06-2019$ & 27 & - & - & - & - & - & \\
$07-06-2019$ & 35 & 27,0000 & - & - & - & - & \\
$08-06-2019$ & 30 & 27,8000 & 27,0000 & 28,6000 & 0,0889 & 28,6889 & 10,0000 \\
$09-06-2019$ & 40 & 28,0200 & 27,0800 & 28,9600 & 0,1044 & 29,0644 & 32,3000 \\
$\ldots$ & $\ldots$ & $\ldots$ & $\ldots$ & $\ldots$ & $\ldots$ & $\ldots$ & $\ldots$ \\
$28-09-2019$ & 41 & 35,1629 & 35,2780 & 34,4152 & $-0,0479$ & 34,3673 & 13,9560 \\
$29-09-2019$ & 43 & 34,8466 & 35,2349 & 35,6890 & 0,0252 & 35,7142 & 18,0584 \\
$30-09-2019$ & 35 & 36,2158 & 35,2576 & 37,1739 & 0,1065 & 37,2804 & 0,7360 \\
& & & & & & & \\
\hline
\end{tabular}


Tabel 4. Peramalan Piroxicam KF 20mg menggunakan Metode Triple Exponential Smoothing

\begin{tabular}{|c|c|c|c|c|c|c|c|c|c|}
\hline Tanggal & $\begin{array}{l}\text { Pen- } \\
\text { jualan }\end{array}$ & $\begin{array}{c}\text { Single } \\
\text { Exponential }\end{array}$ & $\begin{array}{c}\text { Double } \\
\text { Exponential }\end{array}$ & $\begin{array}{c}\text { Triple } \\
\text { Exponential }\end{array}$ & $\mathrm{a}$ & b & $\mathrm{c}$ & $\begin{array}{l}\text { Pera- } \\
\text { malan }\end{array}$ & $\begin{array}{l}\text { APE } \\
(\%)\end{array}$ \\
\hline 05-06-2019 & 25 & - & - & - & - & - & - & - & - \\
\hline 06-06-2019 & 27 & 25 & - & - & - & - & - & - & - \\
\hline 07-06-2019 & 35 & 25.2000 & 25,0000 & - & - & - & - & - & - \\
\hline 08-06-2019 & 30 & 26.1800 & 25.0200 & 25,0000 & 28,48 & 3,15 & 1,14 & 32,20 & 7,34 \\
\hline 09-06-2019 & 40 & 26.5620 & 25.1360 & 25.0020 & 29,28 & 2,67 & 1,29 & 33,60 & 16,00 \\
\hline $10-06-2019$ & 47 & 27.9058 & 25.2786 & 25.0154 & 32,90 & 6,73 & 2,36 & 40,82 & 13,16 \\
\hline 11-06-2019 & 23 & 29.8152 & 25.5413 & 25.0417 & 37,86 & 10,8 & 3,77 & 50,58 & 119,9 \\
\hline$\ldots$ & $\ldots$ & $\ldots$ & $\ldots$ & & $\ldots$ & $\ldots$ & & $\ldots$ & $\ldots$ \\
\hline 26-09-2019 & 32 & 35.5143 & 35.2658 & 34.7134 & 35,46 & $-0,3$ & $-0,30$ & 34,97 & 9,28 \\
\hline 27-09-2019 & 32 & 35.1629 & 35.2906 & 34.7686 & 34,39 & $-1,3$ & $-0,64$ & 32,74 & 2,32 \\
\hline 28-09-2019 & 41 & 34.8466 & 35.2778 & 34.8208 & 33,52 & $-2,1$ & $-0,88$ & 31,05 & 24,26 \\
\hline 29-09-2019 & 43 & 35.4619 & 35.2347 & 34.8665 & 35,55 & $-0,1$ & $-0,14$ & 35,42 & 17,62 \\
\hline 30-09-2019 & 35 & 36.2157 & 35.2574 & 34.9033 & 37,78 & 1,98 & 0,604 & 40,06 & 14,45 \\
\hline
\end{tabular}

Tabel 5. Peramalan Piroxicam KF 20mg menggunakan Weighted Moving Average

\begin{tabular}{clll}
\hline Tanggal & Penjualan & Peramalan & APE (\%) \\
\hline $08-06-2019$ & 30 & 31,25 & 4,17 \\
$09-06-2019$ & 40 & 30,82 & 22,95 \\
$10-06-2019$ & 47 & 33,07 & 29,64 \\
$11-06-2019$ & 23 & 36,79 & 59,94 \\
$12-06-2019$ & 38 & 33,82 & 10,99 \\
$\ldots$ & $\ldots$ & $\ldots$ & $\ldots$ \\
$26-09-2019$ & 32 & 35,64 & 11.39 \\
$27-09-2019$ & 32 & 34,54 & 7,92 \\
$28-09-2019$ & 41 & 33,71 & 17,77 \\
$28-09-2019$ & 43 & 35,36 & 17,77 \\
$30-09-2019$ & 35 & 37,43 & 6,94 \\
& & & \\
\hline
\end{tabular}

Tabel 6. Peramalan Piroxicam KF 20mg menggunakan ARIMA

\begin{tabular}{ccccc}
\hline \multicolumn{3}{c}{ Parameter } & \multicolumn{2}{c}{ APE (\%) } \\
\cline { 1 - 3 } $\mathrm{p}$ & \multicolumn{2}{c}{$\mathrm{d}$} & $\mathrm{Q}$ & \\
\hline 0 & 0 & 0 & 15,159 \\
0 & 0 & 1 & 15,639 \\
0 & 0 & 2 & 15,103 \\
0 & 1 & 0 & 18,334 \\
0 & 1 & 1 & 15,403 \\
$\ldots$ & & $\ldots$ & $\ldots$ \\
10 & 0 & 2 & 16,565 \\
10 & 1 & 0 & 17,224 \\
10 & 1 & 1 & 17,023 \\
10 & 1 & 2 & 17,115 \\
10 & 2 & 0 & 18,782 \\
& & & \\
\hline
\end{tabular}

Tabel 7. Peramalan Piroxicam KF 20mg menggunakan LSTM

\begin{tabular}{clll}
\hline Tanggal & Penjualan & Peramalan & APE (\%) \\
\hline $08-06-2019$ & 30 & 29,4021 & 3,9567 \\
$09-06-2019$ & 40 & 40,7857 & 5,5460 \\
$10-06-2019$ & 47 & 46,4783 & 0,7334 \\
$11-06-2019$ & 23 & 25,6039 & 1,9931 \\
$12-06-2019$ & 38 & 38,6903 & 1,9643 \\
$\ldots$ & $\ldots$ & $\ldots$ & $\ldots$ \\
$26-09-2019$ & 32 & 29,0310 & 9,2782 \\
$27-09-2019$ & 32 & 30,3765 & 5,0734 \\
$28-09-2019$ & 41 & 37,3916 & 8,8009 \\
$28-09-2019$ & 43 & 40,6898 & 5,3727 \\
$30-09-2019$ & 35 & 31,5497 & 9,8579 \\
& & & \\
\hline
\end{tabular}


Tabel 8. Rekapitulasi nilai MAPE

\begin{tabular}{ll}
\hline \multicolumn{1}{c}{ Peramalan } & MAPE (\%) \\
\hline Least Square & 15,9124 \\
Single Exponential Smoothing & 15,6719 \\
Double Exponential Smoothing & 16,2871 \\
Triple Exponential Smoothing & 23,2503 \\
Moving Average & 16,0739 \\
ARIMA & 14,6210 \\
LSTM & 4,6151 \\
\end{tabular}

Tabel 8 menampilkan rekapitulasi nilai MAPE untuk seluruh metode yang diujikan. Berdasarkan informasi yang diperoleh, metode LSTM memiliki nilai MAPE terendah sebesar 4,6151\%. Dengan hasil tersebut, dilanjutkan penggunaan metode LSTM untuk peramalan harian dan peramalan mingguan untuk produk-produk sediaan farmasi di apotek. Produk yang diramalkan permintaannya adalah produk kategori A sesuai prinsip dasar pada klasifikasi ABC, yakni produk-produk yang secara kumulatif berkontribusi terhadap $80 \%$ nilai penjualan (Rupiah). Terdapat 546 produk sediaan farmasi pada kategori A seperti diilustrasikan rekapitulasinya pada gambar 12. Obat pada Kategori A tersebut adalah obat dengan penjualan $80 \%$ dari total penjualan seluruh obat di Apotek Suganda.

\begin{tabular}{|c|c|c|c|c|}
\hline & Nama Obat & Penjualan & Komulatif Penjualan & Persentase \\
\hline 932 & Piroxicam KF $20 \mathrm{mg}$ Tab & 9595000.0 & 9595000.0 & 0.010807 \\
\hline 881 & Lerzin $10 \mathrm{mg}$ Caps $50 \mathrm{~s}$ & 9216000.0 & 18811000.0 & 0.021187 \\
\hline 931 & Piroxicam If $20 \mathrm{mg}$ Tab $120 \mathrm{~s}$ & 8400000.0 & 27211000.0 & 0.030647 \\
\hline 39 & Ambroxol Tablet $30 \mathrm{mg} 100 \mathrm{~s}$ & 8263500.0 & 35474500.0 & 0.039955 \\
\hline 424 & Fenamin $500 \mathrm{mg}$ Tablet $100 \mathrm{~s}$ & 7654500.0 & 43128000.0 & 0.048576 \\
\hline$\ldots$ & $\ldots$ & $\ldots$ & $\ldots$ & .. \\
\hline 387 & Erlamycetin $1 \%$ Salep Mata $3,5 \mathrm{mg}$ & 469000.0 & 708059000.0 & 0.797480 \\
\hline 861 & $\mathrm{OBH}$ Combi Anak Madu & 468000.0 & 708527000.0 & 0.798007 \\
\hline 246 & Comtusi Syrup $60 \mathrm{ml}$ & 468000.0 & 708995000.0 & 0.798534 \\
\hline 901 & Pacetik 500 & 468000.0 & 709463000.0 & 0.799081 \\
\hline 562 & Ikaderm 0,05\% Cream $10 \mathrm{gr}$ & 468000.0 & 709931000.0 & 0.799588 \\
\hline
\end{tabular}

Gambar 12. Data produk kategori A

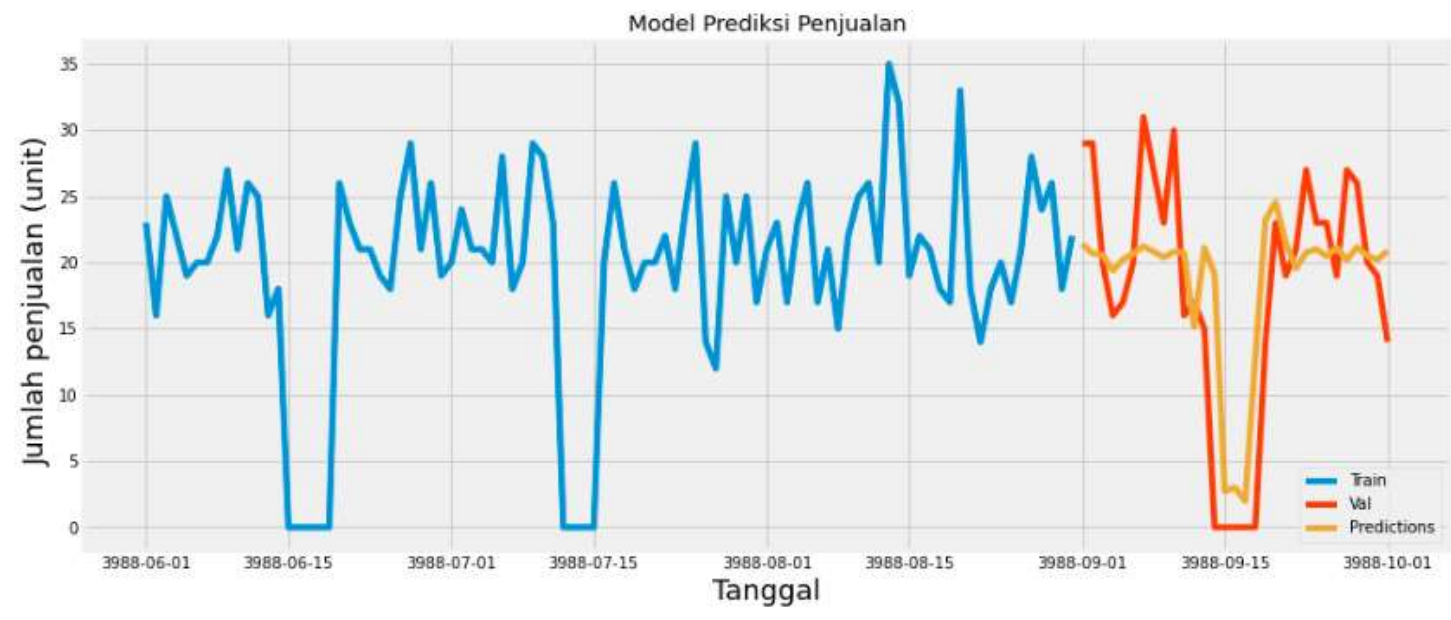

Gambar 13. Grafik peramalan produk nomor 40 (Ambroxol Tablet 30mg 100s)

Gambar 13 menyajikan ilustrasi data latih (training) selama tiga bulan dari Juni sampai Agustus. Kemudian data uji (testing) di bulan September 2019 dan data prediksi untuk September 2019. Paremeter yang digunakan adalah n_steps 6 dan epoch 100. Hasil itu menujukkan secara umum bahwa LSTM cukup baik melakukan estimasi. 
Hasil peramalan harian menggunakan metode LSTM terhadap produk pada kategori A ditampilkan pada gambar 16.(a) dan hasil peramalan mingguan pada gambar 16.(b). Pada peramalan harian didapatkan nilai MAPE terendah $0.8743 \%$, nilai MAPE tertinggi $7.9201 \%$ dan nilai MAPE rata-rata $4.6541 \%$. Pada peramalan mingguan didapatkan nilai MAPE terendah $0,0032 \%$, nilai MAPE tertinggi 13,5276\% dan nilai MAPE rata-rata 4,7109\%. Secara umum dapat dilihat bahwa nilai MAPE untuk peramalan harian dan peramalan mingguan tidak jauh berbeda.

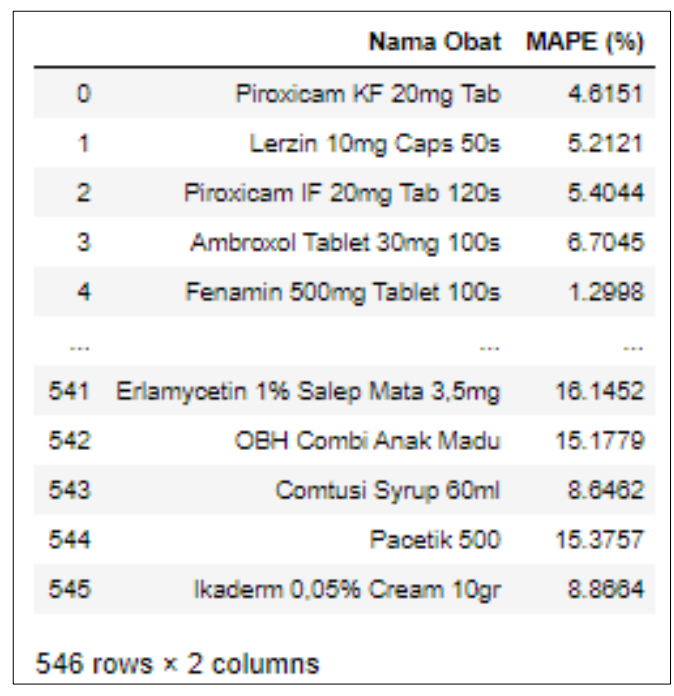

(a)

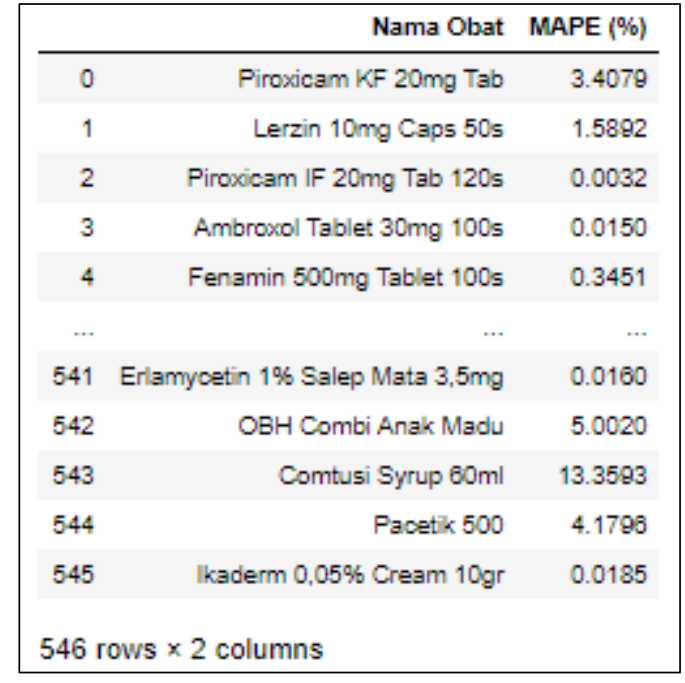

(b)

Gambar 14. Peramalan permintaan (a) harian dan (b) mingguan menggunakan LSTM pada produk kategori A

Metode LSTM membutuhkan pengaturan parameter berupa n_steps dan epochs. Parameter n_steps adalah jumlah data yang dijadikan sebagai masukan ke dalam neuron atau syaraf dari LSTM untuk kemudian dilakukan peramalan satu step di depan data sepanjang jumlah data tersebut. Epochs adalah banyaknya jumlah iterasi yang digunakan untuk penghitungan peramalan LSTM. Nilai n_steps dicari antara 2 hingga 9 menggunakan walk-forward validation. Adapun parameter epochs yang digunakan adalah 100 dan 500. Hasil dari pencarian parameter n_steps pada epochs 100 dan 500 ditampilkan pada Tabel 9.

Tabel 9. Hasil pencarian n_steps ideal pada Epoch 100 dan 500

\begin{tabular}{lcccccccl}
\hline n_steps & \multicolumn{3}{c}{ MAPE Perbulan } & $\begin{array}{c}\text { Epoch } \\
100\end{array}$ & & MAPE Perbulan & $\begin{array}{l}\text { Epoch } \\
500\end{array}$ \\
\hline & Juni & Juli & Agustus & Rata-rata & Juni & Juli & Agustus & Rata-rata \\
\hline 2 & $5,90 \%$ & $2,63 \%$ & $4,12 \%$ & $4,22 \%$ & $-4,13 \%$ & $2,89 \%$ & $4,41 \%$ & $3,81 \%$ \\
3 & $4,87 \%$ & $3,13 \%$ & $3,42 \%$ & $3,81 \%$ & $-1,60 \%$ & $1,77 \%$ & $5,28 \%$ & $2,89 \%$ \\
4 & $4,47 \%$ & $2,23 \%$ & $3,48 \%$ & $3,39 \%$ & $-1,02 \%$ & $1,43 \%$ & $1,77 \%$ & $1,41 \%$ \\
5 & $17,89 \%$ & $2,94 \%$ & $3,86 \%$ & $8,23 \%$ & $19,09 \%$ & $1,84 \%$ & $8,17 \%$ & $9,70 \%$ \\
6 & $12,46 \%$ & $3,71 \%$ & $2,26 \%$ & $6,15 \%$ & $10,25 \%$ & $5,67 \%$ & $6,60 \%$ & $7,51 \%$ \\
7 & $4,08 \%$ & $6,30 \%$ & $6,02 \%$ & $5,47 \%$ & $6,46 \%$ & $3,74 \%$ & $3,52 \%$ & $4,58 \%$ \\
8 & $3,17 \%$ & $8,11 \%$ & $5,48 \%$ & $5,59 \%$ & $-5,60 \%$ & $11,16 \%$ & $7,80 \%$ & $8,18 \%$ \\
9 & $0,12 \%$ & $6,02 \%$ & $4,38 \%$ & $3,51 \%$ & $2,20 \%$ & $9,26 \%$ & $6,25 \%$ & $5,90 \%$ \\
\hline
\end{tabular}

Berdasarkan informasi dari tabel 9, parameter n_steps pada epochs 100 dan 500, diketahui bahwa n_steps 4 memiliki nilai MAPE terendah. Pada epochs 100, nilai MAPE n_steps 4 adalah 3,39\% dan pada epochs 500, nilai MAPE n_steps 4 adalah 1,41\%. Dengan demikian, n_steps sebesar 4 dipakai untuk mencari pengaruh epoch terhadap hasil peramalan LSTM. 
Tabel 10. Hasil pengujian LSTM untuk menentukan epoch ideal

\begin{tabular}{|c|c|c|c|c|c|}
\hline \multirow[t]{2}{*}{ epoch } & \multicolumn{3}{|c|}{ MAPE Perbulan } & \multirow{2}{*}{$\begin{array}{c}\text { MAPE } \\
\text { Rata-rata }\end{array}$} & \multirow{2}{*}{$\begin{array}{c}\text { Waktu rata-rata } \\
\text { (detik) }\end{array}$} \\
\hline & Juni & Juli & Agustus & & \\
\hline 100 & $5,23 \%$ & $3,24 \%$ & $2,63 \%$ & $3,70 \%$ & 8,15 \\
\hline 200 & $-4,00 \%$ & $1,08 \%$ & $2,41 \%$ & $2,50 \%$ & 14,58 \\
\hline 300 & $-1,81 \%$ & $1,13 \%$ & $2,83 \%$ & $1,92 \%$ & 24,90 \\
\hline 400 & $2,77 \%$ & $-2,41 \%$ & $0,10 \%$ & $1,76 \%$ & 33,92 \\
\hline 500 & $-8,22 \%$ & $0,00 \%$ & $1,11 \%$ & $3,11 \%$ & 43,24 \\
\hline
\end{tabular}

Tabel 10 menampilkan rata-rata MAPE untuk beberapa parameter yakni epoch 100, 200, hingga 500. Secara umum dapat dilihat bahwa mulai dari epoch 100 ke epoch 400 terjadi penurunan MAPE, namun ketika epoch diperbesar menjadi 500, nilai MAPE ternyata naik tajam menjadi $3,11 \%$. Oleh karena epoch merupakan jumlah iterasi dalam proses pembentukan model LSTM menggunakan data training, maka semakin besar nilai epoch semakin lama proses iterasi dilakukan.

LSTM dengan parameter n_steps sebesar 4 dan epoch sebesar 400 dapat dapat digunakan untuk membentuk model LSTM menggunakan data training dan melakukan proses prediksi atau peramalan. Selanjutnya, metode tersebut idealnya dibuatkan menjadi sebuah modul program peramalan untuk aplikasi penjualan (PoS) yang dimiliki oleh Apotek Suganda. Namun demikian, perlu juga dipertimbangkan waktu training karena untuk setiap produk, dibentuk model LSTM sendiri-sendiri sehingga bisa diestimasikan berapa waktu yang dibutuhkan untuk training saja. Jika ada 546 produk (kategori A), sedangkan waktu yang dibutuhkan untuk training selama 33,92 detik untuk tiap produk, maka total dibutuhkan waktu sekitar 18520,32 detik atau sekitar 5,1445 jam. Waktu tersebut belum termasuk waktu untuk prediksi atau peramalan.

Pada penelitian ini, diasumsikan bahwa setiap jenis produk memiliki pola dan tren permintaan yang tidak berbeda. Idealnya, dilakukan terlebih dahulu proses pengelompokan produk berdasarkan karakter data time series penjualan, tidak semata didasarkan nilai penjualan sebagaimana klasifikasi $\mathrm{ABC}$ tradisional yang diilustrasikan pada artikel ini. Hal ini karena nilai kontribusi penjualan tidak mempertimbangkan pola dan tren data time series. Pola (pattern) dan tren atau kecenderungan data (trend) pada data time series sangat berpengaruuh terhadap kualitas peramalan. Dengan demikian, pemilihan parameter untuk suatu metode peramalan bisa dipengaruhi kedua hal tersebut.

\section{Simpulan}

Penggunaan LSTM untuk peramalan penjualan sediaan farmasi pada Apotek Suganda ternyata cukup akurat yang ditunjukkan oleh nilai rata-rata persentasi kesalahan peramalan atau nilai MAPE sekitar 4\%. Tidak ada perbedaan signifikan antara nilai MAPE untuk peramalan permintaan produk secara harian maupun mingguan, yakni berturut-turut $4.6541 \%$ dan $4,7109 \%$. Parameter $n \_s t e p s$ ideal yang digunakan untuk peramalan adalah sebesar 4 sedangkan epoch sebesar 100.

Namun demikian, di dalam implementasinya untuk pembuatan modul program peramalan yang akan diintegrasikan pada aplikasi penjualan, perlu dipertimbangkan waktu yang diperlukan untuk proses pembentukan model LSTM menggunakan data training. Ternyata waktu yang dibutuhkan untuk training cukup lama sekitar 5,14 jam untuk data sebanyak 546 produk saja.

\section{Ucapan Terima Kasih}

Terima kasih kepada LPPM Universitas Sebelas Maret yang memberikan kesempatan untuk melakukan Riset Mandiri pada tahun 2020 (Nomor Kontrak 124/UN27.21/HK/2020). 


\section{Daftar Pustaka}

Abraham, B., \& Ledolter, J. (2009). Statistical methods for forecasting (Vol. 234): John Wiley \& Sons.

Affandi, L., Pradibta, H., \& Habibi, M. I. (2018). PERAMALAN STOK OBAT DI PUSKESMAS GENDING PROBOLINGGO MENGUNAKAN METODE WINTER'S EXPONENTIAL SMOOTHING. Jurnal Informatika Polinema, 4(4), 274-274.

Aprilianto, T., \& Fauzi, I. (2016). Perancangan Sistem Peramalan Penjualan Barang Pada UD Achmad Jaya Dengan Metode Triple Exponential Smoothing. Jurnal Ilmiah Teknologi Informasi Asia, 10(2), 73-86.

Arfan, A. (2019). Prediksi Harga Saham Di Indonesia Menggunakan Algoritma Long Short-Term Memory. Paper presented at the Prosiding SeNTIK.

Brownlee. [online]. https://machinelearningmastery.com/how-to-develop-lstm-modelsfor-time-series-forecasting/ (Diakses 21 Januari 2020)

ElMoaqet, H., Tilbury, D. M., \& Ramachandran, S. K. (2016). Multi-Step Ahead Predictions for Critical Levels in Physiological Time Series. IEEE Trans Cybern, 46(7), 1704-1714. doi:10.1109/tcyb.2016.2561974

Erl, T., Khattak, W., \& Buhler, P. (2016). Big Data Fundamentals: Concepts, Drivers, and Techniques: Prentice Hall.

Essnet Validat Foundation. (2016). Methodology for data validation 1.0.

Fachrurrazi, S. (2019). Peramalan Penjualan Obat Menggunakan Metode Single Exponential Smoothing Pada Toko Obat Bintang Geurugok. TECHSI-Jurnal Teknik Informatika, 7(1), 19-30.

Friedman, J., Hastie, T., \& Tibshirani, R. (2001). The elements of statistical learning (Vol. 1): Springer series in statistics New York.

Guo, Y., Liu, Y., Oerlemans, A., Lao, S., Wu, S., \& Lew, M. (2016). Deep learning for visual understanding: a review. J Neurocompt, 187( 6), 27-48.

Hastomo, W., \& Satyo, A. (2019). Long Short Term Memory Machine Learning Untuk Memprediksi Akurasi Nilai Tukar IDR Terhadap USD. Paper presented at the Prosiding SeNTIK.

Hendriani, T., Yamin, M., \& Dewi, A. P. (2016). Sistem Peramalan Persediaan Obat Dengan Metode Weight Moving Average Dan Reorder Point (Studi Kasus: Puskesmas Soropia). semanTIK, 2(2).

Kotler, P., \& Keller, K. L. (2009). Manajemen Pemasaran Edisi 13, Jilid I, Jakarta.

Kumalasari, A., \& Rochmah, T. N. (2016). Pengendalian Persediaan Obat Generik Dengan Metode MMSL (Minimum-Maximum Stock Level) di Unit Farmasi Rumah Sakit Islam Surabaya. Jurnal Manajemen Kesehatan Yayasan RS. Dr. Soetomo, 2(2), 143-152.

Makridakis, S., Spiliotis, E., \& Assimakopoulos, V. (2018). Statistical and Machine Learning forecasting methods: Concerns and ways forward. PLOS ONE, 13(3), 126. doi:10.1371/journal.pone.0194889

Rahmawati, I., \& Wijanarko, R. (2019). Implementasi Prediksi Penjualan Obat Menggunakan Metode Least Square Pada Apotek Demak Farma Jaya. Jurnal Informatika dan Rekayasa Perangkat Lunak, 1(1).

Render, B., Stair Jr, R. M., \& Hanna, M. E. (2012). Quantitative Analysis For Management.

Sugiartawan, P., Permana, A. A. J., \& Prakoso, P. I. (2018). Forecasting Kunjungan Wisatawan Dengan Long Short Term Memory (LSTM). Jurnal Sistem Informasi dan Komputer Terapan Indonesia (JSIKTI), 1(1), 43-52. 
Witten, I. H., \& Frank, E. (2002). Data mining: practical machine learning tools and techniques with Java implementations. Acm Sigmod Record, 31(1), 76-77.

Zahra, I. A. (2019). Analisis Perbandingan Teknik Peramalan Kebutuhan Obat Dengan Metode Arima Dan Single Eksponensial Smoothing Studi Kasus: Rsud Indramayu. Jurnal Tata Kelola dan Kerangka Kerja Teknologi Informasi, 9(1).

Lampiran 1 Kode untuk melakukan peramalan dengan LSTM (Brownlee, 2020)

import pandas as pd

import csv

import mysql.connector as sql

import numpy as np

from keras.models import Sequential

from keras.layers import LSTM

from keras.layers import Dense

from keras.layers import Bidirectional

import time

$\mathrm{db}=$ sql.connect(host='localhost', user='root', passwd=", database='phppos')

cur $=$ db.cursor ()

\# mendapatkan data penjualan semua produk

cur.execute('SELECT * FROM modul_clean_sales')

result $=$ cur.fetchall $(0$

head $=[\mathrm{h}[0]$ for $\mathrm{h}$ in cur.description $]$

sales_items $=$ pd.DataFrame $($ result, columns=head $)$

\# mengambil data penjualan id 964

def get_data(item_id):

product $=$ sales_items.copy ()

product $=$ product.loc $[$ product $[$ 'item_id'] ==item_id $]$

\# membersihkan data penjualan 0

sale $=[\mathrm{x}$ for $\mathrm{x}$ in product ['clean_sale'] $]$

date $=[\mathrm{x}$ for $\mathrm{x}$ in product ['time'] $]$

data $=[(\mathrm{x}, \mathrm{y})$ for $\mathrm{x}, \mathrm{y}$ in zip $($ date, sale $)]$

clean_sales = pd.DataFrame $($ data, columns $=[$ 'time','sales'] $)$

clean_sales.replace $(0$, np.nan, inplace $=$ True $)$

clean_sales['time'] = pd.to_datetime(clean_sales['time'])

clean_sales = clean_sales.set_index (['time'])

\# melakukan imputasi terhadap data penjualan

if((np.array(clean_sales['sales'])[0])>0):

clean_sales['clean'] = clean_sales['sales'].interpolate(method='time').apply(lambda x: round(x)) else:

clean_sales['sales'][0] $=0$

clean_sales['clean'] = clean_sales['sales'].interpolate(method='time').apply(lambda x: round(x)) return clean_sales

def split_sequence(sequence, n_steps):

$\mathrm{X}, \mathrm{y}=\operatorname{list}(\mathrm{)}, \operatorname{list}()$

for $\mathrm{i}$ in range(len(sequence)):

end_ix $=\mathrm{i}+\mathrm{n} \_$steps

if end_ix > len(sequence) -1 :

break

seq_x, seq_y = sequence[i:end_ix], sequence[end_ix]

$\mathrm{X}$.append(seq_x)

y.append(seq_y)

return np.array $(\mathrm{X})$, np.array $(\mathrm{y})$

def forecast(len_data, e, item_id):

$\mathrm{p}=[\mathrm{x}$ for $\mathrm{x}$ in get_data(item_id)['clean']]

n_steps $=4$

raw_seq $=$ np.array $(p)\left[0: l e n \_d a t a+n \_s t e p s\right]$

actual $=$ np.array $(p)[$ len_data + n_steps $]$

$\mathrm{X}, \mathrm{y}=$ split_sequence(raw_seq, n_steps)

n_features $=1$

$\mathrm{X}=$ X.reshape((X.shape[0], X.shape[1], n_features))

model $=$ Sequential ()

model.add(Bidirectional(LSTM(50, activation='relu'), input_shape=(n_steps, n_features) $)$ )

model.add(Dense(1))

model.compile(optimizer='adam', loss='mse')

model.fit $(X, y$, epochs $=e$, verbose $=0)$

X_input $=$ raw_seq[len_data: $]$

x_input $=$ x_input.reshape $\left(\left(1, n_{-}\right.\right.$steps, $n_{-}$features $\left.)\right)$

yhat $=$ model.predict $\left(x_{-}\right.$input, verbose $\left.=0\right)$

return [actual, yhat[0][0]]

result $=[]$

$\mathrm{fn}=$ ['train_size', 'n_steps', 'actual', 'forecast'] 


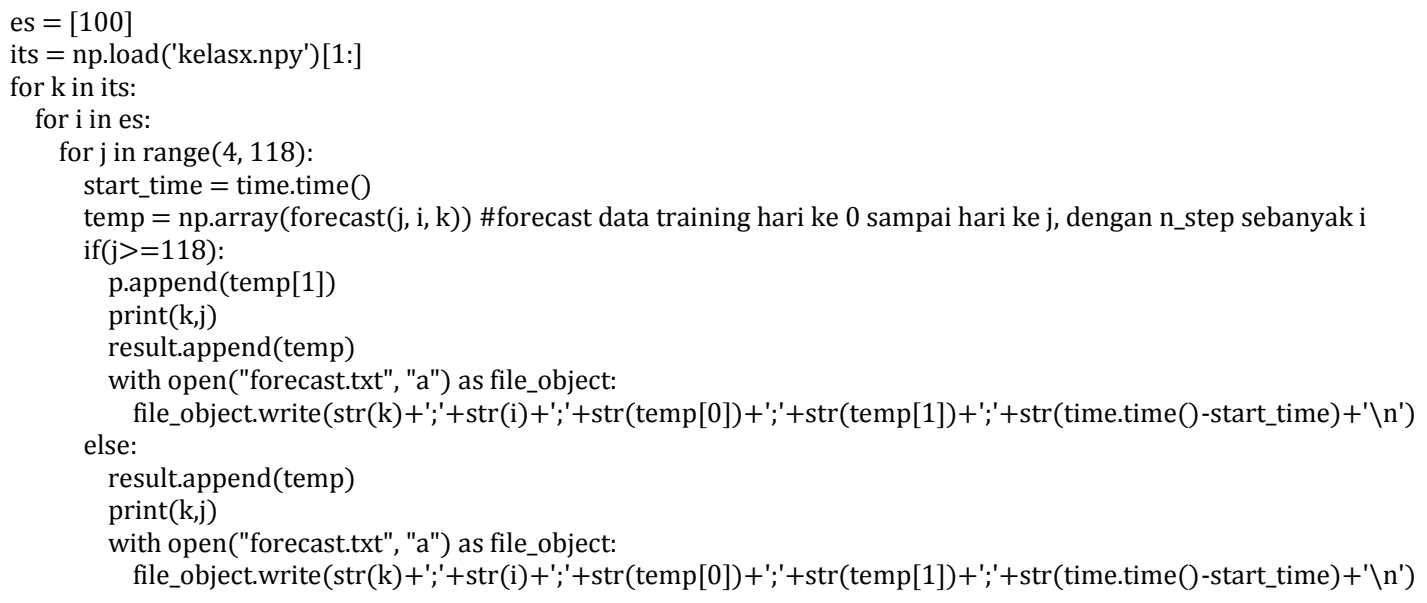

Lampiran 2 Tabel data penjualan di Apotek Suganda (telah dibersihkan)

\begin{tabular}{|c|c|c|c|c|c|c|c|c|c|c|c|}
\hline Date & 39 & 40 & 41 & 961 & 962 & 963 & 964 & 965 & 966 & 1261 & 1262 \\
\hline $6 / 1 / 2019$ & 1 & 23 & 5 & 0 & 2 & 25 & 35 & 0 & 0 & 0 & 2 \\
\hline $6 / 2 / 2019$ & 0 & 16 & 8 & 0 & 3 & 26 & 32 & 0 & 0 & 0 & 3 \\
\hline $6 / 3 / 2019$ & 2 & 25 & 10 & 0 & 2 & 25 & 28 & 0 & 0 & 0 & 2 \\
\hline $6 / 4 / 2019$ & 0 & 22 & 5 & 1 & 3 & 16 & 40 & 0 & 1 & 0 & 1 \\
\hline $6 / 5 / 2019$ & 1 & 19 & 5 & 1 & 2 & 18 & 25 & 0 & 0 & 0 & 2 \\
\hline $6 / 6 / 2019$ & 0 & 20 & 6 & 1 & 1 & 18 & 27 & 0 & 0 & 0 & 0 \\
\hline $6 / 7 / 2019$ & 1 & 20 & 9 & 0 & 3 & 25 & 35 & 0 & 0 & 0 & 0 \\
\hline $6 / 8 / 2019$ & 0 & 22 & 7 & 3 & 2 & 18 & 30 & 0 & 0 & 1 & 3 \\
\hline $6 / 9 / 2019$ & 0 & 27 & 4 & 1 & 1 & 24 & 40 & 0 & 0 & 0 & 4 \\
\hline $6 / 10 / 2019$ & 1 & 21 & 4 & 3 & 4 & 24 & 47 & 0 & 0 & 1 & 0 \\
\hline $6 / 11 / 2019$ & 0 & 26 & 5 & 2 & 3 & 17 & 23 & 0 & 1 & 0 & 2 \\
\hline $6 / 12 / 2019$ & 0 & 25 & 9 & 0 & 2 & 22 & 38 & 0 & 0 & 1 & 2 \\
\hline $6 / 13 / 2019$ & 2 & 16 & 5 & 0 & 2 & 45 & 0 & 0 & 0 & 1 & 2 \\
\hline $6 / 14 / 2019$ & 2 & 18 & 5 & 1 & 2 & 20 & 0 & 0 & 0 & 0 & 3 \\
\hline $6 / 15 / 2019$ & 0 & 0 & 4 & 0 & 2 & 13 & 35 & 1 & 0 & 0 & 2 \\
\hline $6 / 16 / 2019$ & 0 & 0 & 4 & 0 & 2 & 31 & 19 & 0 & 0 & 0 & 4 \\
\hline $6 / 17 / 2019$ & 0 & 0 & 3 & 2 & 3 & 23 & 31 & 0 & 0 & 0 & 4 \\
\hline $6 / 18 / 2019$ & 1 & 0 & 2 & 2 & 3 & 24 & 45 & 0 & 0 & 0 & 2 \\
\hline $6 / 19 / 2019$ & 0 & 0 & 0 & 2 & 3 & 22 & 36 & 0 & 0 & 0 & 1 \\
\hline $6 / 20 / 2019$ & 0 & 26 & 0 & 2 & 2 & 23 & 43 & 0 & 0 & 1 & 4 \\
\hline $6 / 21 / 2019$ & 0 & 23 & 0 & 3 & 2 & 21 & 44 & 0 & 0 & 2 & 1 \\
\hline $6 / 22 / 2019$ & 2 & 21 & 0 & 4 & 2 & 0 & 37 & 0 & 0 & 3 & 1 \\
\hline $6 / 23 / 2019$ & 1 & 21 & 0 & 2 & 2 & 0 & 40 & 0 & 0 & 0 & 4 \\
\hline $6 / 24 / 2019$ & 0 & 19 & 5 & 0 & 3 & 21 & 40 & 0 & 1 & 0 & 1 \\
\hline $6 / 25 / 2019$ & 0 & 18 & 9 & 0 & 3 & 19 & 25 & 1 & 0 & 0 & 2 \\
\hline $6 / 26 / 2019$ & 0 & 25 & 4 & 0 & 3 & 16 & 36 & 0 & 0 & 1 & 2 \\
\hline $6 / 27 / 2019$ & 0 & 29 & 7 & 0 & 3 & 14 & 22 & 1 & 0 & 0 & 2 \\
\hline $6 / 28 / 2019$ & 2 & 21 & 7 & 0 & 3 & 20 & 29 & 0 & 0 & 1 & 1 \\
\hline $6 / 29 / 2019$ & 2 & 26 & 11 & 1 & 3 & 22 & 33 & 0 & 0 & 0 & 3 \\
\hline $6 / 30 / 2019$ & 2 & 19 & 5 & 0 & 3 & 24 & 36 & 0 & 0 & 0 & 0 \\
\hline $7 / 1 / 2019$ & 0 & 20 & 6 & 2 & 3 & 26 & 40 & 1 & 0 & 1 & 0 \\
\hline $7 / 2 / 2019$ & 1 & 24 & 8 & 1 & 2 & 22 & 22 & 0 & 0 & 1 & 0 \\
\hline $7 / 3 / 2019$ & 1 & 21 & 3 & 0 & 3 & 17 & 37 & 0 & 0 & 1 & 0 \\
\hline $7 / 4 / 2019$ & 0 & 21 & 8 & 0 & 3 & 13 & 33 & 0 & 0 & 0 & 1 \\
\hline $7 / 5 / 2019$ & 0 & 20 & 4 & 1 & 3 & 28 & 38 & 0 & 0 & 0 & 3 \\
\hline $7 / 6 / 2019$ & 0 & 28 & 4 & 0 & 3 & 16 & 35 & 0 & 0 & 1 & 3 \\
\hline $7 / 7 / 2019$ & 0 & 18 & 1 & 3 & 1 & 20 & 28 & 0 & 0 & 0 & 2 \\
\hline $7 / 8 / 2019$ & 1 & 20 & 4 & 1 & 2 & 19 & 31 & 0 & 0 & 0 & 1 \\
\hline 7/9/2019 & 0 & 29 & 4 & 0 & 2 & 21 & 29 & 0 & 0 & 0 & 2 \\
\hline $7 / 10 / 2019$ & 0 & 28 & 5 & 1 & 3 & 28 & 36 & 0 & 0 & 0 & 3 \\
\hline $7 / 11 / 2019$ & 1 & 23 & 2 & 2 & 2 & 25 & 49 & 0 & 0 & 1 & 1 \\
\hline $7 / 12 / 2019$ & 0 & 0 & 13 & 0 & 3 & 16 & 40 & 0 & 0 & 0 & 3 \\
\hline $7 / 13 / 2019$ & 1 & 0 & 6 & 1 & 2 & 28 & 36 & 0 & 0 & 1 & 2 \\
\hline $7 / 14 / 2019$ & 1 & 0 & 0 & 1 & 2 & 18 & 37 & 0 & 0 & 0 & 3 \\
\hline $7 / 15 / 2019$ & 1 & 0 & 6 & 2 & 3 & 23 & 38 & 0 & 0 & 1 & 2 \\
\hline $7 / 16 / 2019$ & 1 & 20 & 1 & 2 & 3 & 18 & 32 & 0 & 0 & 1 & 0 \\
\hline $7 / 17 / 2019$ & 1 & 26 & 2 & 1 & 3 & 33 & 33 & 0 & 1 & 1 & 3 \\
\hline $7 / 18 / 2019$ & 2 & 21 & 7 & 1 & 2 & 14 & 32 & 0 & 0 & 1 & 1 \\
\hline $7 / 19 / 2019$ & 2 & 18 & 3 & 4 & 2 & 24 & 23 & 1 & 0 & 0 & 2 \\
\hline $7 / 20 / 2019$ & 2 & 20 & 4 & 1 & 4 & 22 & 0 & 0 & 0 & 0 & 1 \\
\hline $7 / 21 / 2019$ & 1 & 20 & 7 & 0 & 3 & 19 & 0 & 0 & 0 & 0 & 4 \\
\hline $7 / 22 / 2019$ & 1 & 22 & 4 & 1 & 2 & 32 & 0 & 0 & 0 & 1 & 3 \\
\hline $7 / 23 / 2019$ & 0 & 18 & 5 & 0 & 2 & 29 & 0 & 0 & 1 & 0 & 1 \\
\hline
\end{tabular}




\begin{tabular}{|c|c|c|c|c|c|c|c|c|c|c|c|}
\hline Date & 39 & 40 & 41 & 961 & 962 & 963 & 964 & 965 & 966 & 1261 & 1262 \\
\hline $7 / 24 / 2019$ & 1 & 24 & 8 & 0 & 3 & 23 & 0 & 0 & 0 & 0 & 2 \\
\hline $7 / 25 / 2019$ & 0 & 29 & 9 & 1 & 2 & 21 & 0 & 0 & 0 & 1 & 3 \\
\hline $7 / 26 / 2019$ & 1 & 14 & 4 & 1 & 2 & 25 & 0 & 0 & 0 & 0 & 2 \\
\hline $7 / 27 / 2019$ & 0 & 12 & 5 & 1 & 3 & 23 & 0 & 0 & 0 & 0 & 1 \\
\hline $7 / 28 / 2019$ & 2 & 25 & 5 & 1 & 2 & 28 & 0 & 0 & 0 & 0 & 2 \\
\hline $7 / 29 / 2019$ & 0 & 20 & 5 & 0 & 1 & 24 & 37 & 1 & 0 & 2 & 2 \\
\hline $7 / 30 / 2019$ & 1 & 25 & 6 & 0 & 2 & 18 & 35 & 0 & 1 & 0 & 7 \\
\hline $7 / 31 / 2019$ & 0 & 17 & 0 & 0 & 3 & 19 & 43 & 0 & 0 & 0 & 0 \\
\hline 8/1/2019 & 1 & 21 & 2 & 0 & 3 & 27 & 27 & 1 & 0 & 0 & 1 \\
\hline $8 / 2 / 2019$ & 1 & 23 & 7 & 0 & 2 & 21 & 43 & 0 & 2 & 0 & 2 \\
\hline $8 / 3 / 2019$ & 0 & 17 & 6 & 0 & 3 & 24 & 29 & 0 & 0 & 1 & 3 \\
\hline $8 / 4 / 2019$ & 0 & 23 & 8 & 0 & 4 & 29 & 29 & 0 & 0 & 0 & 3 \\
\hline $8 / 5 / 2019$ & 2 & 26 & 4 & 3 & 2 & 26 & 37 & 0 & 0 & 1 & 2 \\
\hline $8 / 6 / 2019$ & 0 & 17 & 6 & 0 & 2 & 19 & 40 & 0 & 0 & 1 & 1 \\
\hline $8 / 7 / 2019$ & 0 & 21 & 3 & 2 & 3 & 19 & 41 & 0 & 0 & 1 & 0 \\
\hline $8 / 8 / 2019$ & 0 & 15 & 7 & 0 & 2 & 29 & 28 & 0 & 0 & 0 & 2 \\
\hline 8/9/2019 & 1 & 22 & 3 & 2 & 3 & 28 & 24 & 0 & 0 & 2 & 1 \\
\hline $8 / 10 / 2019$ & 1 & 25 & 8 & 2 & 2 & 20 & 30 & 1 & 0 & 0 & 4 \\
\hline $8 / 11 / 2019$ & 1 & 26 & 5 & 1 & 2 & 12 & 35 & 0 & 0 & 0 & 0 \\
\hline $8 / 12 / 2019$ & 1 & 20 & 10 & 2 & 2 & 14 & 30 & 0 & 0 & 0 & 3 \\
\hline $8 / 13 / 2019$ & 3 & 35 & 4 & 3 & 2 & 31 & 30 & 0 & 0 & 0 & 1 \\
\hline $8 / 14 / 2019$ & 0 & 32 & 8 & 1 & 3 & 20 & 39 & 0 & 0 & 0 & 2 \\
\hline $8 / 15 / 2019$ & 3 & 19 & 3 & 2 & 3 & 21 & 41 & 0 & 0 & 0 & 2 \\
\hline $8 / 16 / 2019$ & 0 & 22 & 9 & 2 & 3 & 24 & 32 & 0 & 0 & 0 & 3 \\
\hline $8 / 17 / 2019$ & 2 & 21 & 4 & 2 & 2 & 25 & 32 & 0 & 0 & 0 & 1 \\
\hline $8 / 18 / 2019$ & 1 & 18 & 6 & 3 & 2 & 16 & 46 & 0 & 1 & 0 & 1 \\
\hline $8 / 19 / 2019$ & 2 & 17 & 4 & 1 & 3 & 25 & 37 & 0 & 0 & 1 & 2 \\
\hline $8 / 20 / 2019$ & 0 & 33 & 9 & 0 & 2 & 25 & 31 & 0 & 0 & 0 & 2 \\
\hline $8 / 21 / 2019$ & 1 & 18 & 5 & 2 & 1 & 17 & 36 & 0 & 0 & 1 & 3 \\
\hline $8 / 22 / 2019$ & 1 & 14 & 2 & 2 & 2 & 20 & 40 & 0 & 0 & 0 & 0 \\
\hline $8 / 23 / 2019$ & 1 & 18 & 0 & 0 & 2 & 0 & 33 & 1 & 0 & 0 & 3 \\
\hline $8 / 24 / 2019$ & 1 & 20 & 0 & 0 & 2 & 0 & 26 & 0 & 0 & 1 & 2 \\
\hline $8 / 25 / 2019$ & 0 & 17 & 0 & 0 & 2 & 0 & 38 & 1 & 0 & 2 & 0 \\
\hline $8 / 26 / 2019$ & 0 & 21 & 0 & 0 & 2 & 0 & 30 & 0 & 0 & 1 & 4 \\
\hline $8 / 27 / 2019$ & 0 & 28 & 0 & 0 & 3 & 0 & 29 & 0 & 0 & 1 & 1 \\
\hline $8 / 28 / 2019$ & 3 & 24 & 11 & 2 & 2 & 0 & 30 & 0 & 0 & 0 & 1 \\
\hline $8 / 29 / 2019$ & 0 & 26 & 2 & 1 & 2 & 0 & 30 & 0 & 0 & 0 & 3 \\
\hline $8 / 30 / 2019$ & 0 & 18 & 1 & 1 & 2 & 0 & 27 & 0 & 0 & 0 & 1 \\
\hline $8 / 31 / 2019$ & 1 & 22 & 5 & 0 & 2 & 0 & 40 & 0 & 0 & 1 & 0 \\
\hline 9/1/2019 & 0 & 29 & 4 & 0 & 2 & 0 & 33 & 0 & 0 & 0 & 4 \\
\hline $9 / 2 / 2019$ & 0 & 29 & 7 & 0 & 2 & 21 & 37 & 0 & 0 & 1 & 2 \\
\hline $9 / 3 / 2019$ & 1 & 20 & 3 & 4 & 1 & 15 & 30 & 0 & 0 & 0 & 0 \\
\hline $9 / 4 / 2019$ & 0 & 16 & 10 & 0 & 2 & 19 & 39 & 0 & 0 & 0 & 0 \\
\hline $9 / 5 / 2019$ & 0 & 17 & 4 & 3 & 1 & 23 & 51 & 0 & 0 & 0 & 0 \\
\hline $9 / 6 / 2019$ & 0 & 20 & 5 & 0 & 2 & 23 & 28 & 0 & 0 & 0 & 0 \\
\hline $9 / 7 / 2019$ & 0 & 31 & 4 & 0 & 2 & 23 & 39 & 0 & 0 & 1 & 0 \\
\hline $9 / 8 / 2019$ & 0 & 27 & 7 & 0 & 2 & 18 & 37 & 0 & 0 & 0 & 0 \\
\hline 9/9/2019 & 0 & 23 & 6 & 0 & 2 & 17 & 45 & 0 & 0 & 0 & 3 \\
\hline $9 / 10 / 2019$ & 0 & 30 & 7 & 1 & 2 & 21 & 31 & 0 & 0 & 0 & 1 \\
\hline $9 / 11 / 2019$ & 0 & 16 & 7 & 0 & 2 & 17 & 37 & 0 & 0 & 0 & 1 \\
\hline $9 / 12 / 2019$ & 3 & 17 & 7 & 0 & 3 & 25 & 27 & 0 & 0 & 1 & 3 \\
\hline $9 / 13 / 2019$ & 1 & 15 & 7 & 2 & 2 & 19 & 37 & 0 & 0 & 2 & 2 \\
\hline $9 / 14 / 2019$ & 1 & 0 & 3 & 1 & 2 & 25 & 33 & 0 & 0 & 1 & 1 \\
\hline $9 / 15 / 2019$ & 1 & 0 & 0 & 2 & 2 & 17 & 42 & 0 & 1 & 0 & 5 \\
\hline $9 / 16 / 2019$ & 0 & 0 & 0 & 0 & 2 & 20 & 42 & 0 & 0 & 0 & 2 \\
\hline $9 / 17 / 2019$ & 2 & 0 & 0 & 0 & 2 & 23 & 25 & 0 & 0 & 0 & 1 \\
\hline $9 / 18 / 2019$ & 0 & 0 & 0 & 2 & 3 & 25 & 32 & 0 & 0 & 0 & 0 \\
\hline $9 / 19 / 2019$ & 0 & 14 & 0 & 0 & 2 & 15 & 40 & 0 & 0 & 0 & 5 \\
\hline $9 / 20 / 2019$ & 0 & 23 & 0 & 2 & 2 & 18 & 38 & 0 & 0 & 1 & 4 \\
\hline $9 / 21 / 2019$ & 2 & 19 & 6 & 2 & 2 & 23 & 39 & 0 & 0 & 1 & 0 \\
\hline $9 / 22 / 2019$ & 1 & 21 & 9 & 1 & 3 & 17 & 30 & 1 & 0 & 1 & 2 \\
\hline $9 / 23 / 2019$ & 0 & 27 & 7 & 2 & 2 & 21 & 37 & 0 & 0 & 0 & 0 \\
\hline $9 / 24 / 2019$ & 0 & 23 & 6 & 1 & 3 & 24 & 37 & 0 & 0 & 0 & 1 \\
\hline $9 / 25 / 2019$ & 0 & 23 & 7 & 2 & 1 & 20 & 34 & 0 & 0 & 0 & 2 \\
\hline $9 / 26 / 2019$ & 0 & 19 & 7 & 1 & 0 & 24 & 32 & 0 & 0 & 0 & 4 \\
\hline $9 / 27 / 2019$ & 0 & 27 & 6 & 2 & 0 & 23 & 32 & 2 & 0 & 0 & 2 \\
\hline $9 / 28 / 2019$ & 1 & 26 & 5 & 1 & 0 & 26 & 41 & 0 & 0 & 0 & 3 \\
\hline $9 / 29 / 2019$ & 0 & 20 & 4 & 1 & 0 & 16 & 43 & 0 & 0 & 0 & 5 \\
\hline $9 / 30 / 2019$ & 0 & 19 & 8 & 2 & 0 & 22 & 35 & 0 & 0 & 0 & 0 \\
\hline $10 / 1 / 2019$ & 1 & 14 & 8 & 0 & 0 & 0 & 33 & 0 & 0 & 3 & 1 \\
\hline
\end{tabular}

